\title{
KEMAMPUAN PEMECAHAN MASALAH MATEMATIS MELALUI MODEL PEMBELAJARAN SEACRH, SOLVE, CREATE AND SHARE (SSCS) MENGGUNAKAN MEDIA LKPD PADA MATERI PENYAJIAN DATA UNTUK SISWA KELAS VII SMP NEGERI 3 KEPANJEN
}

\author{
Putri Setyo Hartanti ${ }^{1}$ \\ ${ }^{I}$ SMP Negeri 3 Kepanjen \\ Email: ${ }^{1}$ putrisetyo02@gmail.com
}

\begin{abstract}
Abstrak
Penelitian ini dilatar belakangi oleh rendahnya kemampuan pemecahan masalah matematis siswa. Penelitian ini bertujuan untuk: (1) Mengetahui perbedaan kemampuan pemecahan masalah matematis siswa melalui model pembelajaran SSCS menggunakan media LKPD dengan model model pembelajaran konvensional pada materi Penyajian Data untuk siswa kelas VII SMP Negeri 3 Kepanjen, (2) Mendeskripsikan kemampuan pemecahan masalah matematis siswa melalui model pembelajaran SSCS menggunakan media LKPD pada materi Penyajian Data untuk siswa kelas VII SMP Negeri 3 Kepanjen. Jenis penelitian yang digunakan adalah penelitian kombinasi (mixed methods). Pada tahap pertama, penelitian dilakukan menggunakan pendekatan kuntitatif dengan desain quasy experimental, selanjutnya pada tahap kedua penelitian menggunakan pendekatan kualitatif. Data dalam penelitian tahap pertama ini diperoleh dengan melakukan tes kemampuan pemecahan masalah matematis. Data pada penelitin tahap kedua ini diperoleh dengan metode wawancara dan observasi. Hasil penelitian ini: (1) Hasil analisis data kuantitatif dengan uji hipotesis menggunakan software SPSS 20 diperoleh nilai Sig. $=0.022<0.05$ maka $H_{0}$ ditolak atau $H_{l}$ diterima. Hal ini berarti dapat disimpulkan bahwa terdapat perbedaan kemampuan pemecahan maslaah matematis antara siswa yang diajar dengan model pembelajaraan SSCS menggunakan media LKPD dengan siswa yang diajar dengan model pembelajaran komvensional. (2) Berdasarkan analisis data kualitatif yang diperoleh dari wawancara dapat disimpulkan bahwa siswa yang memiliki kemampuan pemecahan masalah matematis tinggi telah memenuhi semua indikator kemampuan pemecahan masalah matematis, siswa yang memiliki kemampuan pemecahan masalah matematis sedang hanya memenuhi 2 indikator kemampuan pemecahan masalah matematis, dan untuk siswa yang memiliki kamampuan pemecahan masalah matematis rendah hanya memenuhi satu indikator kemampuan pemecahan masalah matematis. Kemampuan pemecahan masalah matematis siswa yang diajar dengan model pembelajaran SSCS menggunakan media LKPD termasuk dalam kategori sedang, yang dapat dilihat dari hasil rata-rata posttest menunjukkan nilai sebesar 79.6.
\end{abstract}

Kata-kata kunci: kemampuan pemecahan masalah matematis, model pembelajaran SSCS, LKPD, penyajian data.

\section{PENDAHULUAN}

Pendidikan adalah usaha sadar untuk menyiapkan peserta didik agar dapat berperan aktif dan positif dalam hidupnya sekarang dan yang akan datang. Pada kurikulum tentang sistem pendidikan nasional, matematika merupakan salah satu mata pelajaran wajib bagi siswa sekolah pada jenjang pendidikan dasar dan menengah.

Matematika adalah ilmu dasar yang dapat digunakan sebagai alat bantu memecahkan masalah dalam berbagai bidang ilmu. Dengan belajar matematika siswa dapat berlatih menggunakan pikirannya secara logis, analitis, sistematis, kritis, dan kreatif serta memiliki kemampuan bekerjasama dalam menghadapi berbagai masalah serta mampu memanfaatkan informasi yang diterimanya. Tuntutan kemampuan yang harus dimiliki siswa dalam matematika tidak hanya kemampuan berhitung saja, tetapi kemampuan bernalar yang logis dan kritis dalam 
pemecahan masalah. Pemecahan masalah dalam hal ini tidak hanya masalah yang berupa soal rutin akan tetapi permasalahan yang dihadapi dalam kehidupan sehari-hari.

Polya (dalam Hendriana, 2017: 44) mengemukakan bahwa pemecahan masalah adalah suatu usaha mencari jalan keluar dari suatu tujuan yang tidak begitu mudah segera dapat dicapai. Dalam pemecahan masalah, siswa dituntut memiliki kemampuan menciptakan gagasan-gagasan atau caracara baru berkenaan dengan permasalahan yang dihadapinya.

Berdasarkan hasil pengamatan peneliti secara langsung di SMP Negeri 3 Kepanjen, kemampuan pemecahan masalah siswa belum sepenuhnya dikembangkan. Hal ini yang mengakibatkan kemampuan pemecahan masalah siswa tergolong rendah. Berdasarkan hasil studi pendahuluan di sekolah juga, dalam kegiatan pembelajaran guru hanya memberikan materi berupa rumus tanpa menjelaskan darimana konsep rumus tersebut diperoleh dan kegunaannya dalam memecahkan suatu masalah sehingga kemampuan berpikir siswa tidak berkembang. Guru lebih aktif menjelaskan materi dan siswa dituntut untuk mendengar, mencatat penjelasan guru, serta menyelesaikan latihan soal yang diberikan oleh guru. Hal tersebut yang membuat pembelajaran matematika masih bersifat terpacu pada guru (teacher centered).

Berdasarkan uraian di atas dapat disimpulkan bahwa untuk mengembangkan kemampuan pemecahan masalah siswa, maka siswa harus diikutsertakan dalam kegiatan memecahkan suatu masalah. Rendahnya kualitas kemampuan berpikir matematis siswa tidak terlepas dari kegiatan pembelajaran di kelas. Banyak sekali faktor-faktor yang mempengaruhi diantaranya guru, teman, lingkungan belajar, sarana prasarana, dan model pembelajaran yang digunakan. Salah satu model pembelajaran yang diharapkan dapat membentuk kemampuan pemecahan masalah siswa dalam memecahkan suatu masalah dan siswa ikut terlibat secara aktif dalam kegiatan pembelajaran tersebut adalah model pembelajaran Search, Solve, Create and Share (SSCS).

Model pembelajaran SSCS merupakan salah satu model pembelajaran yang pertama kali dikembangkan oleh Pizzini pada tahun 1988 pada mata pelajaran Sains (IPA). Selanjutnya Pizzini, dkk. (dalam Irwan, 2011:3) menyempurnakan model ini dan menyatakan bahwa model ini tidak hanya berlaku untuk Pendidikan Sains saja, tetapi juga cocok untuk Pendidikan Matematika. Model pembelajaran SSCS ini terdiri dari empat fase/langkah menyelesaikan masalah yang urutannya dimulai dengan menyelidiki masalah (search), merencanakan pemecahan masalah (solve), mengkonstruksi masalah (create), dan mengkomunikasikan penyelesaian yang diperoleh (share). Model pembelajaran SSCS melibatkan siswa dalam menyelidiki sesuatu, membangkitkan minat siswa untuk bertanya serta memecahkan masalah-masalah yang nyata.

Dalam pembelajaran matematika guru harus bisa menciptakan pembelajaran yang kreatif dan memfasilitasi siswa dengan berbagai media pembelajaran yang mampu menumbuhkan kemampuan pemecahan masalah siswa. Lembar Kerja Peserta Didik (LKPD) merupakan salah satu sarana untuk membantu dan mempermudah dalam kegiatan belajar mengajar sehingga akan terbentuk interaksi yang efektif antara peserta didik dengan pendidik, sehingga dapat meningkatkan aktifitas peserta didik dalam peningkatan prestasi belajar.

Berdasarkan uraian di atas, maka peneliti akan mengadakan penelitian dengan judul "Kemampuan Pemecahan Masalah Matematis Melalui Model Pembelajaran Search, Solve, Create and Share (SSCS) Menggunakan Media LKPD Pada Materi Penyajian Data Untuk Siswa Kelas VII SMP Negeri 3 Kepanjen"

Berdasarkan uraian di atas, rumusan masalah dalam penelitian ini adalah: (1) Apakah terdapat perbedaan antara kemampuan pemecahan masalah matematis siswa melalui model pembelajaran search, solve, create and share (SSCS) dengan model pembelajaran konvensional menggunakan media LKPD pada materi Penyajian Data untuk siswa kelas VII SMP Negeri 3 Kepanjen?, (2) Bagaimanakah kemampuan pemecahan masalah matematis siswa melalui model pembelajaran search, solve, create and share (SSCS) menggunakan media LKPD pada materi Penyajian Data untuk siswa kelas VII SMP Negeri 3 Kepanjen?. 
Sesuai dengan rumusan masalah di atas, tujuan penelitian ini adalah: (1) Mengetahui adanya perbedaan antara kemampuan pemecahan masalah matematis siswa melalui model pembelajaran search, solve, create and share (SSCS) menggunakan media LKPD dengan model pembelajaran konvensional pada materi Penyajian Data untuk siswa kelas VII SMP Negeri 3 Kepanjen, (2) Mendeskripsikan kemampuan pemecahan masalah matematis siswa melalui model pembelajaran search, solve, create and share (SSCS) menggunakan media LKPD pada materi Penyajian Data untuk siswa kelas VII SMP Negeri 3 Kepanjen.

Dalam penelitian ini, kemampuan pemecahan masalah yang akan diukur terdapat 4 indikator: (1) Memahami masalah yang meliputi: mengidentifikasi unsur yang diketahui, unsur yang ditanyakan, dan memeriksa kecukupan unsur untuk penyelesaian masalah, (2) Mengaitkan unsur yang diketahui dan ditanyakan dan merumuskannya dalam bentuk model matematika masalah, (3) Memilih strategi penyelesaian, mengelaborasi dan melaksanakan perhitungan atau menyelesaikan model matematika, dan (4) Menginterpretasi hasil terhadap masalah semula dan memeriksa kembali kebenaran solusi.

\section{METODE}

Penelitian ini menggunakan dua pendekatan yaitu pendekatan kuantitatif dan pendekatan kualitatif, sedangkan metode penelitian ini menggunakan metode penelitian kombinasi (mixed methods). Penelitian ini dibagi menjadi dua tahap yaitu tahap pertama menggunakan pendekatan kuantitatif dan tahap kedua menggunakan pendekatan kualitatif.

Pada tahap pertama yaitu pendekatan kuantitatif, penelitian ini menggunakan jenis penelitian Quasy Experimental atau eksperimen semu dengan desain penelitian Nonequivalent Control Group Design.

\begin{tabular}{cccc} 
Kelas & \multicolumn{3}{c}{ Tindakan } \\
Eksperimen & Pre-test $(\mathrm{O})$ & Perlakuan (SSCS) & Post-test (X) \\
Kontrol & $\mathrm{O}_{1}$ & $\mathrm{X}$ & $\mathrm{O}_{2}$ \\
$\mathrm{O}_{3}$ & $\mathrm{Y}$ & $\mathrm{O}_{4}$
\end{tabular}

Keterangan:

$\mathrm{O}_{1}$ : Nilai Pre-Test kelas eksperimen

$\mathrm{O}_{2}$ : Nilai Post-Test kelas eksperimen

$\mathrm{O}_{3}$ : Nilai Pre-Test kelas kontrol

$\mathrm{O}_{4}$ : Nilai Post-Test kelas kontrol

$\mathrm{X}$ : Perlakuan dengan model pembelajaran SSCS dengan media LKPD

Y : Perlakuan dengan model pembelajaran konvensional

Populasi dalam penelitian ini adalah seluruh siswa kelas VII SMP Negeri 3 Kepanjen tahun pelajaran 2017/2018. Teknik pengambilan sampel menggunakan teknik cluster random sampling dengan kelas VII A sebagai kelas eksperimen dan kelas VII B sebagai kelas kontrol dimana masingmasing kelas berjumlah 31 siswa. Variabel dalam penelitian ini terdiri atas dua variabel yaitu variabel bebas dan variabel terikat. Variabel bebas dalam penelitian ini adalah model pembelajaran SSCS (Search, Solve, Create and Share) dengan menggunakan media LKPD dan model pembelajaran konvensional. Sedangkan variabel terikat dalam penelitian ini adalah kemampuan pemecahan masalah matematis siswa yang dihasilkan model pembelajaran SSCS dan kemampuan pemecahan masalah matematis siswa yang dihasilkan model pembelajaran konvensional.

Teknik pengumpulan data dalam tahap pertama ini adalah teknik tes. Instrumen yang digunakan dalam penelitian ini adalah instrumen tes untuk memeperoleh data kemampuan pemecahan masalah matematis siswa berupa soal essai/uraian sebanyak 2 butir. Sebelum instrumen tes digunakan dilakukan uji coba pada kelas lain untuk mengetahui validitas dan reliabilitas instrumen tes. Setelah instrumen tes dinyatakan valid dan reliabel, selanjutnya instrument tersebut digunakan untuk memperoleh data kuantitatif kemampuan pemecahan masalah matematis. 
Kemudian, data yang sudah diperoleh dianalisis menggunakan uji normalitas. Setelah itu, data dianalisis lagi menggunakan uji-t dua pihak untuk mengetahui perbedaan kemampuan pemecahan masalah matematis siswa kelas eksperimen dan kelas kontrol. Setelah menganalisis data kuantitatif kemampuan pemecahan masalah matematis siswa, maka untuk menjawab rumusan masalah dan menguji hipotesis peneliti menyajikan data hasil analisis dalam bentuk narasi.

Penelitian pada tahap kedua yaitu menggunakan pendekatan kualitatif. Penentuan sumber data dalam penelitian ini menggunakan teknik purposive sampling, peneliti mengambil beberapa sampel dari kelas eksperimen dan kontrol berdasarkan nilai post-test dan saran dari guru kelas mata pelajaran matematika. Dimana dari kelas eksperimen dan kelas kontrol diambil 3 sampel dengan kriteria 1 siswa memiliki kemampuan pemecahan masalah matematis tinggi, 1 siswa memiliki kemampuan pemecahan masalah matematis sedang, dan 1 siswa yang memiliki kemampuan pemecahan masalah matematis rendah. Teknik pengumpulan data yang digunakan yaitu teknik wawancara dan observasi. Teknik wawancara dilakukan pada siswa kelas eksperimen dan kelas kontrol sedangkan teknik observasi dilakukan melalui kegiatan observasi guru dan siswa. Teknik analisis data yang digunakan yaitu teknik analisis data sebelum di lapangan dan selama di lapangan. Setelah itu dilakukan pengujian keabsahan data untuk mengetahui kredibilitas data menggunakan teknik triangulasi.

Setelah memperoleh hasil analisis data kuantitatif dan kualitatif kemampuan pemecahan masalah matematis siswa, kemudian kedua data tersebut dianalisis kembali. Analisis tersebut dilakukan dengan cara menggabungkan data yang sejenis sehingga data kuantitatif diperkuat dengan data kualitatif. Setelah data dianalisis secara gabungan, maka langkah selanjutnya yaitu membuat kesimpulan dan saran.

\section{HASIL DAN PEMBAHASAN}

Berdasarkan hasil analisis data pretest dan posttest, dapat diketahui bahwa data pretest dan posttest kelas eksperimen dan kelas kontrol telah berdistribusi normal. Untuk hasil uji kesamaan rata-rata data pretest, diperoleh nilai Sig. $(2$-tailed $)=0.762>0.05$. Dengan demikian, $H_{0}$ diterima sehingga tidak terdapat perbedaan rata-rata data pretest yang signifikan antara kelas eksperimen dan kelas kontrol. Hal ini menunjukkan bahwa kemampuan awal pemecahan masalah matematis siswa kelas eksperimen sama dengan kemampuan awal pemecahan masalah matematis siswa kelas kontrol. Sedangkan berdasarkan hasil analisis uji hipotesis dua pihak data posttest, diperoleh nilai Sig. $(2$-tailed $)=0.022<0.05$. Dengan demikian $H_{0}$ diterima sehingga terdapat perbedaan rata-rata data posttest yang signifikan antara kelas eksperimen dan kelas kontrol. Jadi dapat disimpulkan bahwa terdapat perbedaan kemampuan pemecahan masalah matematis yang signifikan antara siswa yang diajar dengan model pembelajaran SSCS dengan media LKPD dan siswa yang diajar dengan model pembelajaran konvensional.

Hasil analisis data kualitatif meliputi hasil analisis data observasi dan wawancara kemampuan pemecahan masalah matematis siswa kelas eksperimen dan kelas kontrol. Berdasarkan hasil analisis data observasi kegiatan guru dan siswa pada kelas eksperimen, dapat diketahui bahwa guru dan siswa telah melaksanakan kegiatan pembelajaran sesuai dengan langkah-langkah model pembelajaran SSCS meliputi menyelidiki masalah (search), merencanakan pemecahan malasah (solve), mengkonstruksi masalah (create), dan mengkomunikasikan penyelesaian yang diperoleh (share). Sedangkan berdasarkan hasil analisis data observasi kegiatan guru dan siswa kelas kontrol, diketahui bahwa guru telah melaksanakan kegiatan pembelajaran sesuai dengan model pembelajaran konvensional, yaitu guru menerangkan materi kemudian memberikan tugas kepada siswa dan siswa diperbolehkan untuk bertanya jika ada yang belum paham tentang materi yang dipelajari.

Berdasarkan hasil analisis data wawancara kemampuan pemecahan masalah matematis siswa kelas eksperimen, diketahui bahwa subjek penelitian pada kelas eksperimen yang memiliki kemampuan pemecahan masalah tinggi telah memenuhi semua indikator kemampuan pemecahan 
masalah matematis, yang meliputi 1) Memahami masalah yang meliputi: mengidentifikasi unsur yang diketahui, unsur yang ditanyakan, dan memeriksa kecukupan unsur untuk penyelesaian masalah, 2) Mengaitkan unsur yang diketahui dan ditanyakan dan merumuskannya dalam bentuk model matematika masalah, 3) Memilih strategi penyelesaian, mengelaborasi dan melaksanakan perhitungan atau menyelesaikan model matematika, dan 4) Menginterpretasi hasil terhadap masalah semula dan memeriksa kembali kebenaran solusi.

Subjek penelitian kelas eksperimen yang memiliki kemampuan pemecahan masalah matematis sedang hanya memenuhi 3 indikator, yaitu 1) Memahami masalah yang meliputi: mengidentifikasi unsur yang diketahui, unsur yang ditanyakan, dan memeriksa kecukupan unsur untuk penyelesaian masalah dan 2) Mengaitkan unsur yang diketahui dan ditanyakan dan merumuskannya dalam bentuk model matematika masalah, dan 3) Memilih strategi penyelesaian, mengelaborasi dan melaksanakan perhitungan atau menyelesaikan model matematika. Sedangkan untuk indikator keempat, yaitu menginterpretasi hasil terhadap masalah semula dan memeriksa kembali kebenaran solusi, siswa belum bisa menuntaskan indikator tersebut karena dari hasil tes menunjukkan jika siswa belum mampu menginterpretasikan hasil yang diperoleh dengan memeriksa kembali hasil penyelesaian ke dalam permasalahan awal.

Subjek penelitian kelas eksperimen yang memiliki kemampuan pemecahan masalah rendah hanya memenuhi indikator pertama, yaitu memahami masalah yang meliputi: mengidentifikasi unsur yang diketahui, unsur yang ditanyakan, dan memeriksa kecukupan unsur untuk penyelesaian masalah. Sedangkan untuk ketiga indikator lainnya, yaitu 1) Mengaitkan unsur yang diketahui dan ditanyakan dan merumuskannya dalam bentuk model matematika masalah, 2) Memilih strategi penyelesaian, mengelaborasi dan melaksanakan perhitungan atau menyelesaikan model matematika, dan 3) Menginterpretasi hasil terhadap masalah semula dan memeriksa kembali kebenaran solusi, siswa belum mampu menuntaskan ketiga indikator tersebut dikarenakan siswa belum mampu mengaitkan unsur yang diketahui dalam permasalahan yang diberikan dan memilih strategi penyelesaiannya serta siswa belum mampu menginterpretasikan hasil penyelesaian dengan memeriksa kembali solusi ke permasalahan awal.

Sedangkan berdasarkan hasil analisis data wawancara kemampuan pemecahan masalah matematis siswa kelas kontrol, diketahui bahwa subjek penelitian pada kelas kontrol yang memiliki kemampuan pemecahan masalah tinggi telah memenuhi semua indikator kemampuan pemecahan masalah matematis, yang meliputi 1) Memahami masalah yang meliputi: mengidentifikasi unsur yang diketahui, unsur yang ditanyakan, dan memeriksa kecukupan unsur untuk penyelesaian masalah, 2) Mengaitkan unsur yang diketahui dan ditanyakan dan merumuskannya dalam bentuk model matematika masalah, 3) Memilih strategi penyelesaian, mengelaborasi dan melaksanakan perhitungan atau menyelesaikan model matematika, dan 4) Menginterpretasi hasil terhadap masalah semula dan memeriksa kembali kebenaran solusi.

Subjek penelitian kelas kontrol yang memiliki kemampuan pemecahan masalah matematis sedang hanya memenuhi indikator 1) Memahami masalah yang meliputi: mengidentifikasi unsur yang diketahui, unsur yang ditanyakan, dan memeriksa kecukupan unsur untuk penyelesaian masalah dan 2) Mengaitkan unsur yang diketahui dan ditanyakan dan merumuskannya dalam bentuk model matematika masalah. Sedangkan untuk indikator 3) Memilih strategi penyelesaian, mengelaborasi dan melaksanakan perhitungan atau menyelesaikan model matematika dan 4) Menginterpretasi hasil terhadap masalah semula dan memeriksa kembali kebenaran solusi, siswa belum bisa menuntaskan kedua indikator tersebut karena dari hasil tes menunjukkan jika siswa belum sepenuhnya mampu menyelesaikan permasalahan dan menginterpretasikan hasil penyelesaian dengan baik.

Subjek penelitian kelas kontrol yang memiliki kemampuan pemecahan masalah rendah hanya memenuhi indikator pertama, yaitu memahami masalah yang meliputi: mengidentifikasi unsur yang diketahui, unsur yang ditanyakan, dan memeriksa kecukupan unsur untuk penyelesaian masalah. Sedangkan untuk ketiga indikator lainnya, yaitu 1) Mengaitkan unsur yang diketahui dan 
ditanyakan dan merumuskannya dalam bentuk model matematika masalah, 2) Memilih strategi penyelesaian, mengelaborasi dan melaksanakan perhitungan atau menyelesaikan model matematika, dan 3) Menginterpretasi hasil terhadap masalah semula dan memeriksa kembali kebenaran solusi, siswa belum mampu menuntaskan ketiga indikator tersebut dikarenakan siswa belum mampu mengaitkan unsur yang diketahui dalam permasalahan yang diberikan dan memilih strategi penyelesaian serta siswa belum mampu menginterpretasikan hasil penyelesaian dengan memeriksa kembali kebenaran dari solusi yang dihasilkan.

Tabel 2. Perbandingan Data Hasil Posttest dan Wawancara

\begin{tabular}{|c|c|c|c|c|c|c|}
\hline \multirow[b]{2}{*}{ No } & \multirow{2}{*}{$\begin{array}{l}\text { Indikator } \\
\text { Kemampuan } \\
\text { Pemecahan } \\
\text { Masalah } \\
\text { Matematis }\end{array}$} & \multicolumn{2}{|c|}{$\begin{array}{c}\text { Data Kuantitatif } \\
(\%)\end{array}$} & \multicolumn{2}{|c|}{ Data Kualitatif } & \multirow[b]{2}{*}{ Kesimpulan } \\
\hline & & $\begin{array}{c}\text { Kelas } \\
\text { Ekspe- } \\
\text { rimen }\end{array}$ & $\begin{array}{c}\text { Kelas } \\
\text { Kon- } \\
\text { trol }\end{array}$ & $\begin{array}{c}\text { Kelas } \\
\text { Eksperimen }\end{array}$ & Kelas Kontrol & \\
\hline 1. & $\begin{array}{l}\text { Memahami masalah } \\
\text { yang meliputi: } \\
\text { mengidentifikasi } \\
\text { unsur yang } \\
\text { diketahui, unsur } \\
\text { yang ditanyakan, } \\
\text { dan memeriksa } \\
\text { kecukupan unsur } \\
\text { untuk penyelesaian } \\
\text { masalah }\end{array}$ & $99 \%$ & $98 \%$ & $\begin{array}{l}\text { Mampu } \\
\text { memahami } \\
\text { masalah yang } \\
\text { meliputi: } \\
\text { mengidentifikasi } \\
\text { unsur yang } \\
\text { diketahui, unsur } \\
\text { yang ditanyakan, } \\
\text { dan memeriksa } \\
\text { kecukupan unsur } \\
\text { untuk } \\
\text { penyelesaian } \\
\text { masalah }\end{array}$ & $\begin{array}{l}\text { Mampu memahami } \\
\text { masalah yang } \\
\text { meliputi: } \\
\text { mengidentifikasi } \\
\text { unsur yang } \\
\text { diketahui, unsur } \\
\text { yang ditanyakan, } \\
\text { dan memeriksa } \\
\text { kecukupan unsur } \\
\text { untuk penyelesaian } \\
\text { masalah }\end{array}$ & $\begin{array}{l}\text { Meleng-kapi, } \\
\text { membukti-kan, } \\
\text { dan memper- } \\
\text { kuat data } \\
\text { kuantitatif }\end{array}$ \\
\hline 2. & $\begin{array}{l}\text { Mengaitkan unsur } \\
\text { yang diketahui dan } \\
\text { ditanyakan dan } \\
\text { merumuskan-nya } \\
\text { dalam bentuk } \\
\text { model matematika } \\
\text { masalah }\end{array}$ & $76 \%$ & $76 \%$ & $\begin{array}{l}\text { Cukup mampu } \\
\text { mengaitkan unsur } \\
\text { yang diketahui } \\
\text { dan ditanyakan } \\
\text { dan } \\
\text { merumuskannya } \\
\text { dalam bentuk } \\
\text { model matematika } \\
\text { masalah }\end{array}$ & $\begin{array}{l}\text { Cukup mampu } \\
\text { mengaitkan unsur } \\
\text { yang diketahui dan } \\
\text { ditanyakan dan } \\
\text { merumuskan-nya } \\
\text { dalam bentuk } \\
\text { model matematika } \\
\text { masalah }\end{array}$ & $\begin{array}{l}\text { Meleng-kapi, } \\
\text { membuktikan, } \\
\text { dan memper- } \\
\text { kuat data } \\
\text { kuantitatif }\end{array}$ \\
\hline 3. & $\begin{array}{l}\text { Memilih strategi } \\
\text { penyelesaian, } \\
\text { mengelaborasi dan } \\
\text { melaksanakan } \\
\text { perhitungan atau } \\
\text { menyelesaikan } \\
\text { model matematika }\end{array}$ & $91 \%$ & $80 \%$ & $\begin{array}{l}\text { Mampu memilih } \\
\text { strategi } \\
\text { penyelesaian, } \\
\text { mengelaborasi } \\
\text { dan melaksanakan } \\
\text { perhitungan atau } \\
\text { menyelesaikan } \\
\text { model matematika }\end{array}$ & $\begin{array}{l}\text { Cukup mampu } \\
\text { memilih strategi } \\
\text { penyelesaian, } \\
\text { mengelaborasi dan } \\
\text { melaksanakan } \\
\text { perhitungan atau } \\
\text { menyelesaikan } \\
\text { model matematika }\end{array}$ & $\begin{array}{l}\text { Meleng-kapi, } \\
\text { membuktikan, } \\
\text { dan memper- } \\
\text { kuat data } \\
\text { kuantitatif }\end{array}$ \\
\hline 4. & $\begin{array}{l}\text { Menginterpretasi } \\
\text { hasil terhadap } \\
\text { masalah semula dan } \\
\text { memeriksa kembali } \\
\text { kebenaran solusi }\end{array}$ & $62 \%$ & $58 \%$ & $\begin{array}{l}\text { Cukup mampu } \\
\text { menginterpretasi } \\
\text { hasil terhadap } \\
\text { masalah semula } \\
\text { dan memeriksa } \\
\text { kembali } \\
\text { kebenaran solusi }\end{array}$ & $\begin{array}{l}\text { Cukup mampu } \\
\text { menginterpreta-si } \\
\text { hasil terhadap } \\
\text { masalah semula dan } \\
\text { memeriksa kembali } \\
\text { kebenaran solusi }\end{array}$ & $\begin{array}{l}\text { Meleng-kapi, } \\
\text { membuktikan, } \\
\text { dan memper- } \\
\text { kuat data } \\
\text { kuantitatif }\end{array}$ \\
\hline
\end{tabular}

Berdasarkan hasil analisis data kuantitatif dan kualitatif yang ditunjukkan pada Tabel 2, dapat diketahui bahwa tidak terdapat perbedaan yang signifikan antara kedua data kuantitatif dan kualitatif kemampuan pemecahan masalah matematis siswa. Dengan demikian, penelitian kualitatif yang dilakukan pada tahap kedua dapat menghasilkan data kualitatif yang dapat membuktikan, 
melengkapi, dan memperkuat data kuantitatif kemampuan pemecahan masalah matematis siswa yang dilakukan pada tahap pertama.

\section{SIMPULAN DAN SARAN}

Berdasarkan hasil penelitian pada mata pelajaran matematika pokok bahasan penyajian data di SMP Negeri 3 Kepanjen kelas VII tahun pelajaran 2017/2018 mengenai kemampuan pemecahan masalah matematis siswa dengan menerapkan model pembelajaran Search, Solve, Create and Share (SSCS) diperoleh simpulan sebagai berikut

1) Berdasarkan hasil analisis statistik uji hipotesis dengan menggunakan Independent Sample $t$ Test dapat disimpulkan bahwa terdapat perbedaan kemampuan pemecahan masalah matematis siswa kelas eksperimen melalui penerapan model pembelajaran SSCS dan kelas kontrol melalui penerapan model pembelajaran konvensinal pada pokok bahasan penyajian data kelas VII SMP Negeri 3 Kepanjen. Hal ini dapat dilihat dari output hasil perhitungan menggunakan software SPSS 20 dengan taraf signifikansi $\alpha=0.05$ diperoleh nilai Sig. $=0.022<0.05$ sehingga $H_{0}$ ditolak dan $H_{l}$ diterima.

2) Berdasarkan hasil analisis data kualitatif yang diperoleh dari wawancara pada kelas eksperimen didapatkan bahwa subjek E8 sudah mampu memenuhi keempat indikator kemampuan pemecahan masalah matematis, subjek E24 sudah mampu memenuhi tiga indikator kemampuan pemecahan masalah matematis, sedangkan subjek E16 hanya mampu memenuhi satu dari keempat indikator kemampuan pemecahan masalah matematis. Berdasarkan hasil observasi, siswa kelas eksperimen lebih aktif dibandingkan dengan siswa kelas kontrol. Analisis data hasil posttest kemampuan pemecahan masalah matematis kelas eksperimen menunjukkan siswa yang memiliki kemampuan pemecahan masalah matematis rendah sebesar $6 \%$, sedang sebesar $29 \%$, dan tinggi sebesar $61 \%$. Sedangkan rata-rata nilai siswa termasuk dalam kategori sedang yaitu 79.6. Dengan demikian, penelitian kualitatif yang dilakukan pada tahap kedua dapat menghasilkan data kualitatif yang dapat membuktikan, melengkapi, dan memperkuat data kantitatif kemampuan pemecahan masalah matematis siswa yang dilakukan pada tahap pertama.

Hasil penelitian ini diharapkan mampu memberikan sumbangan ide-ide dalam upaya meningkatkan kualitas pembelajaran matematika khusunya dalam melatih kemampuan pemecahan masalah matematis siswa.

\section{DAFTAR RUJUKAN}

Hendriana. (2017). Hard Skills dan Soft Skills Matematik Siswa. Bandung: Refika Aditama.

Irwan. (2011). Pengaruh Pendekatan Problem Posing Model Search, Solve, Create and Share (SSCS) Dalam Upaya Meningkatkan Kemampuan Penalaran Matematis Mahasiswa Matematika. Jurnal Penelitian Pendidikan, 12(1), 1-13.

Pizzini, Edward L. (1991). SSCS Implementation Handbook. USA: Science Education Centre TheUniversity of Iowa.

Polya, G. (1957). How to solve it. USA: Princton University press

Wahyudin (2007). Aplikasi Statistika dalam Penelitian. Diktat Perkuliahan, Sekolah Pasca Sarjana UPI, Bandung: Tidak diterbitkan 